\title{
房総半島南端千倉層群における鮮新統一更新統境界層準の古地磁気一酸素同位 体複合層序
}

An integrated stratigraphy around the Plio-Pleistocene boundary interval in the Chikura Group, southernmost part of the Boso Peninsula, central Japan, based on data from paleomagnetic and oxygen isotopic analyses

岡田 誠*1 所 佳実*2 内田剛行*3 荒井裕司 ${ }^{* 4}$ 斉藤敬二 ${ }^{* 5}$

\author{
Makoto Okada*1, Yoshimi Tokoro*2, \\ Yoshiyuki Uchida ${ }^{* 3}$, Yuji Arai ${ }^{* 4}$ and \\ Keiji Saito*5 \\ 2011 年 7 月 5 日受付. \\ 2011 年 11 月 16 日受理. \\ *1 茨城大学理学部 \\ Department of Earth Sciences, Ibaraki Uni- \\ versity, Ibaraki 310-8512, Japan \\ *2 茨城大学理工学研究科 \\ Department of Earth Sciences, Graduate \\ School of Science and Engineering, Ibaraki \\ 310-8512, Japan \\ *3 栃木県信用保証協会 \\ Tochigi Credit Guarantee Corporation, Toch- \\ igi 320-8618, Japan \\ *4 北総産業(株) \\ Kitaso Corporation, Tochigi 320-0038, Japan \\ *5 杤木県警察 \\ Tochigi Police, Tochigi 320-8510, Japan \\ Corresponding author; M. Okada, \\ okada@mx.ibaraki.ac.jp
}

\begin{abstract}
We propose a refined chronostratigraphy for the middle section of the Chikura Group, containing the Plio-Pleistocene boundary, from the southernmost part of the Boso Peninsula, Japan, based on magnetostratigraphy and oxygen isotopic stratigraphic analysis of benthic foraminifers. The stratigraphic interval examined here correlates with the chronostratigraphic interval from the upper Gauss chronozone, including the Kaena sub-chronozone, to the lower Matuyama chronozone. Our chronostratigraphic interpretation strongly suggests that the presently defined stratigraphic interval represents LR04 marine isotope stages (MIS) G16 to 93. The Matuyama-Gauss boundary present within the studied sequence is not within MIS 104, as is described in the LR04 time scale, but is in MIS 103. This interpretation is consistent with that of the boundary's stratigraphic horizon as reported in Mediterranean sapropel stratigraphy.
\end{abstract}

Keywords: Plio-Pleistocene boundary, Boso Peninsula, Chikura Group, magnetostratigraphy, oxygen isotope

\section{はじめに}

房総半島南端地域に分布する鮮新一更新統千倉層群は, 堆 積物の供給源が伊豆・小笠原弧に極めて近いため, 火山砕屑 物の割合が高く, それらが強く安定な古地磁気シグナルを提 供している. それに加え保存良好な微化石を多産するため, 千倉層群は生層序学的研究や古海洋学的研究に適している. さらに千倉層群の平均堆積速度は $70 \mathrm{~cm} / \mathrm{kyr}$ (小竹ほか, 1995）と速いため, 生物源堆積物や風成堆積物が主体となる ような通常の深海底コア試料と比較して遙かに時間解像度の 高い記録を得ることができるという利点がある. 一方, 炭酸 塩補償深度 (CCD) が浅くかつ平均水深の深い北西太平洋海 域の深海底堆積物からは，酸素同位体などを用いた層位学的 研究や古海洋学的研究に欠かすことのできない石灰質微化石 が，海山や海台の頂部などの例外を除いてほとんど産出しな い. 以上のことから，鮮新世一更新世境界付近で開始した北 半球の寒冷化といつた古海洋学的事象を議論する際, 千倉層
群から得られる古海洋情報は, 北西太平洋における数少ない 良質な情報として極めて重要と言える.

最近, 著者らにより千倉層群における古地磁気・酸素同位 体層序の構築が試みられ，これまでに約 1.7〜 3.5 Ma の間 におけるほぼ連続した酸素同位体記録が得られつつある(岡 田ほか, 2010 等). 本論文では, 本研究で得られた古地磁気 および酸素同位体の情報を統合することで, Matuyama/ Gauss 極性境界と酸素同位体ステージとの関係を高精度で 求め, 千倉層群が本邦における鮮新統一更新統境界付近にお ける模式地となり得るための基準層序を提供することを目的 とした.

\section{地質概略および現地調査}

千倉層群は，成瀬ほか（1951）により「千倉累層」として提 唱され，小竹(1988)によって千倉層群として再定義された. 小竹ほか (1995) は, 古地磁気および微化石層位学的研究に より, 千倉層群の年代層序学的な検討を詳細に行つた. その 

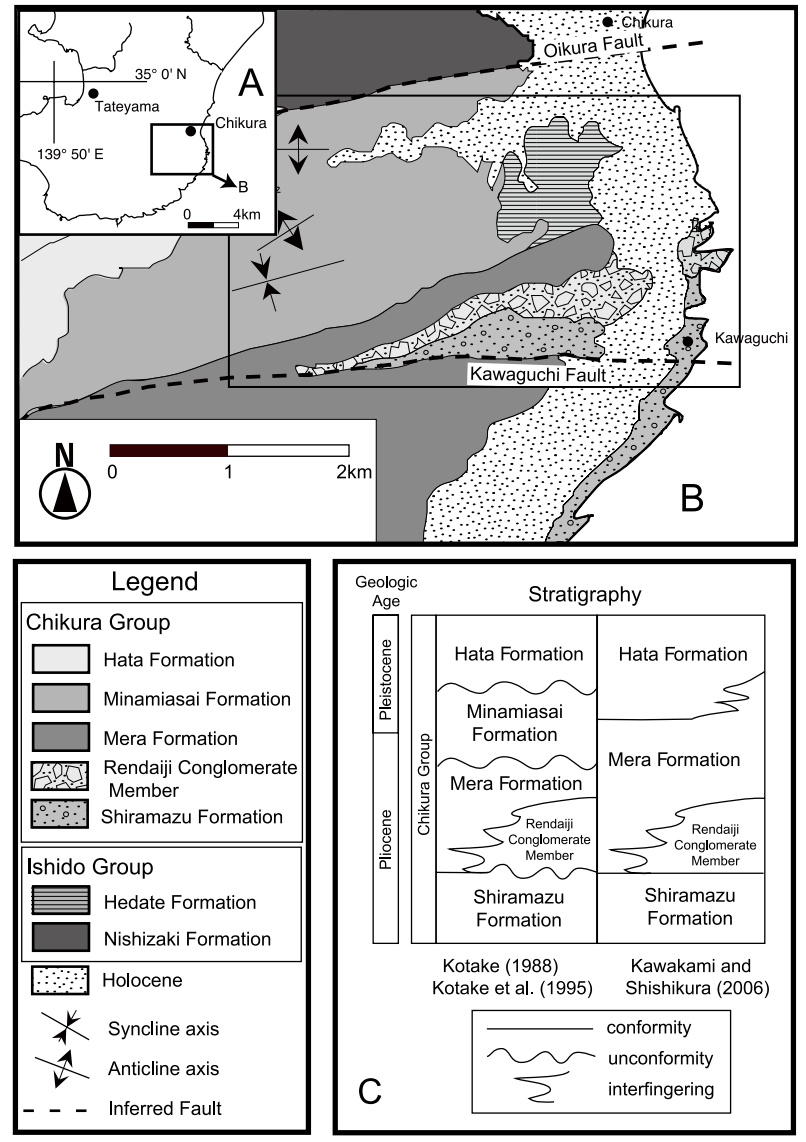

Fig. 1. Geology of the study area. A: Map of the southernmost part of the Boso Peninsula. B: Simplified geology of the study area, modified from Kotake (1988). The square indicates the area of the topographic map in Fig. 2. C: Stratigraphic correlation of the Chikura Group between Kotake (1988), Kotake et al. (1995), and Kawakami and Shishikura (2006).

結果, 大井倉断層および川口断層周辺に分布する千倉層群主 要部が, 下位から白浜層・白間津層・布良層・南朝夷層・畑 層からなり, 白浜層から布良層までは整合, それより上位の 地層群は互いに不整合であること, また後に鮮新一更新統境 界とされた Matuyama/Gauss 境界が南朝夷層に含まれるこ と等が示された (Figs. 1B，1C)。一方，川上・宍倉 (2006) では, 主にテフラ層の詳細な対比により, 千倉層群の再定義 を行った. 彼らは, 小竹 (1988)による南朝夷層に挟在する テフラ層が，より西方に分布する布良層上部のテフラ層と対 比されること等から, 両者の地層が同時堆積の関係にあるこ とを示し, 両者の岩相の類似性から南朝夷層を布良層の一部 とした. さらに上位の畑層との間に同時異層の関係が認めら れること等から, 烟層と布良層の間は整合関係にあるとした (Fig. 1C). また小竹 (1988) で不整合とされた布良層一南朝 夷層境界を断層関係であるとし，その断層と，そこから西方 へとつながる, 川口断層(小竹, 1988)の中西部とを合わせて 「千倉断層」と命名し, 東部の川口断層のみを「川口断層」と再 定義した.

今回著者らは, 小竹(1988)によって提唱された南朝夷層
の模式地である南房総市千倉町の大井倉近傍の林道「千倉線」 周辺の調査を行った. 調査は南房総市発行の $1: 10000$ 縮 尺の地形図を基準として行い, 歩測・レーザー距離計の併用 による測距と, オリエンテーリング用コンパスによる方位測 定により，1：1000 縮尺でルートマップを作成した (Fig. 2). また, 柱状図を $1 / 50$ の縮尺で作成することで, 詳細な 岩相記載と精密な試料採取層準の記録を行つた. 調査の結 果, 林道から南へ延びる沢で, 厚さ $1 \mathrm{~m}$ 以上の砂岩層を挟 む砂質シルト岩層からなる南朝夷層下部が，下位に向かって 塊状シルト岩層へと漸移していることを確認した. 塊状シル 卜岩層は下位に向かって少なくとも層厚 $150 \mathrm{~m}$ 以上は存在 しており，小竹(1988)で定義された布良層であると考えら れた. 野外において両者の岩相は容易に区別可能であるが, 両者の境界付近に明らかな断層関係や不整合関係は確認でき なかつた。

本研究の対象層準は, 小竹 (1988)の定義では「布良層およ び南朝夷層」となり, 川上・宍倉 (2006)では「布良層」となる. これらのどちらを採用しても本研究の内容には直接影響しな い.しかし, 著者らがこれまで行ってきた同層準における層 序学的研究 (亀尾ほか, 2003 等) との整合性をとるため, 本 論文においても小竹 (1988) および小竹ほか (1995)による定 義にしたがうこととした.

\section{研究手法および結果}

\section{1. 古地磁気層序}

1)試料採取および処理 古地磁気測定用試料は, シルト岩層 および砂質シルト岩層を対象とし, 露頭表面の風化層を除い た後, エンジンドリルを用いて直径 $2.5 \mathrm{~cm}$ のコア試料を各 層準につき 3〜 7 本程度採取した. 採取密度は, 層厚間隔に して約 10-25 m 程度である. 古地磁気測定の結果, 極性反 転が見られる層準についてはさらに間隔をつめて試料採取を 行った. 採取したコア試料は, 実験室に持ち帰つた後, ダイ ヤモンドカッターを用いて長さ $2 \mathrm{~cm}$ 程度に切りそろえ, そ れぞれを古地磁気測定用試片とした.

2)測定方法 試料の古地磁気測定は, 茨城大学理学部所有の 超伝導岩石磁力計 SRM-750 (米国 2G 社製), 全自動交流消 磁スピナー磁力計 NP-2 (メトバ社製) および交流消磁装置 DFM-8601 (夏原技研製), 熱消磁電気炉 TDE-91 (夏原技 研製), 熱消磁電気炉 TD-48 (米国 ASC Scientific 社製)を 用いた. 使用内訳は, 層準 $230 \mathrm{~m}$ より上位の採取試料につ いて, 段階交流消磁を全自動スピナー磁力計 NP-2 で行い, 段階熱消磁を熱消磁電気炉 TDE-91 と超伝導磁力計 SRM-750 で行つた. 層準 $230 \mathrm{~m}$ より下位については, 交 流消磁装置 DFM-8601 および熱消磁電気炉 TD-48 を用い て消磁し, 測定は全て超伝導磁力計 SRM-750 を用いて行つ た. 磁力計および消磁装置のシールドケース内の残留磁場は いずれも $5 \mathrm{nT}$ 以下となるよう調整した.

測定は, 各採取地点につき最低 1 つずつのパイロット試 片に対して 0〜 50ないし $60 \mathrm{mT}$ まで $5 \mathrm{mT}$ おきに段階交流 消磁を, また $100 \sim 600{ }^{\circ} \mathrm{C}$ の間において $50{ }^{\circ} \mathrm{C}$ おきに段階 熱消磁を施した. 段階消磁において, 直交座標図上で原点に 


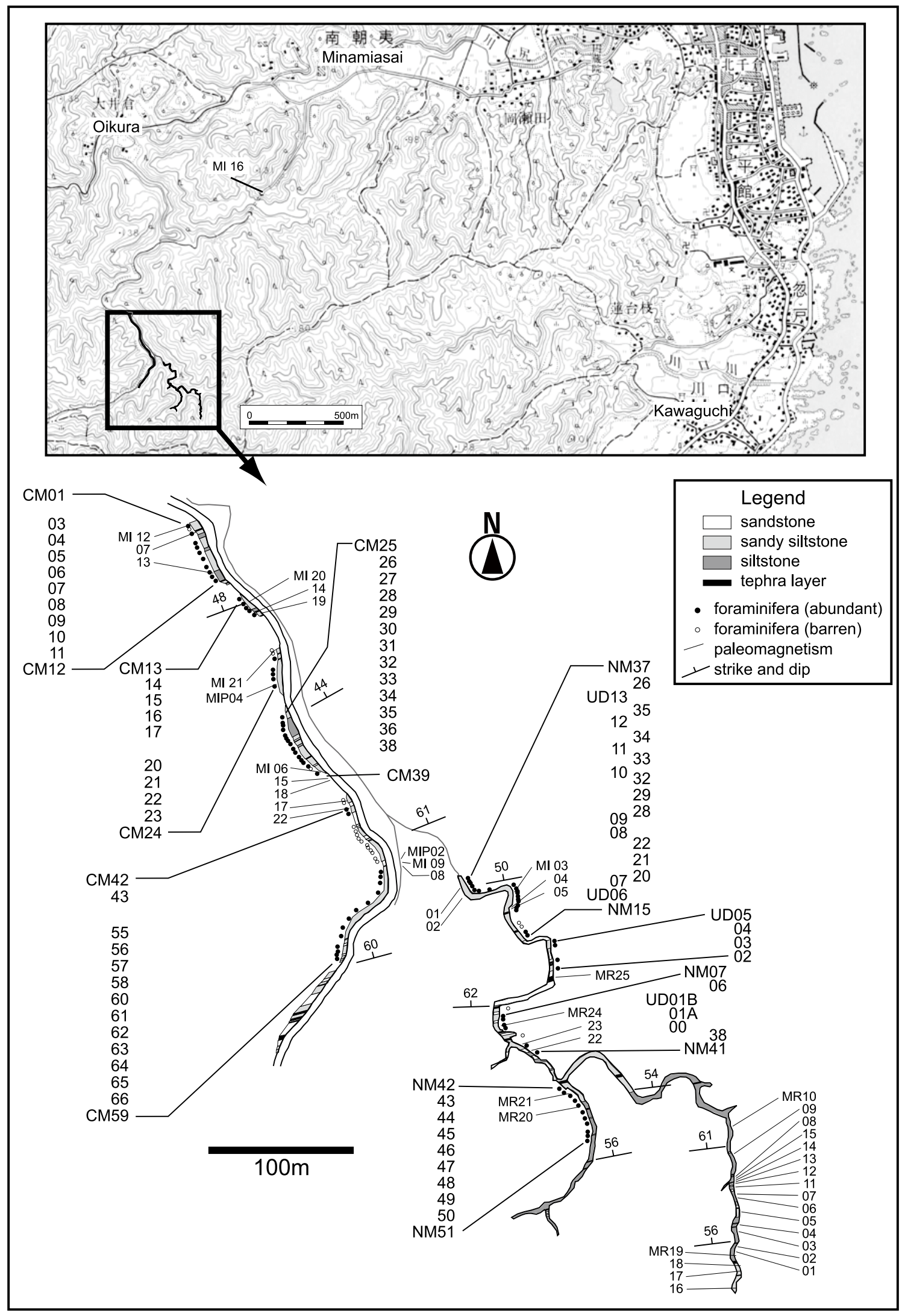

Fig. 2. Lithology and sampling sites within the study area. The topographic map is after the Chikura 1:25,000 map published by the Geographical Survey Institute in 1992. 

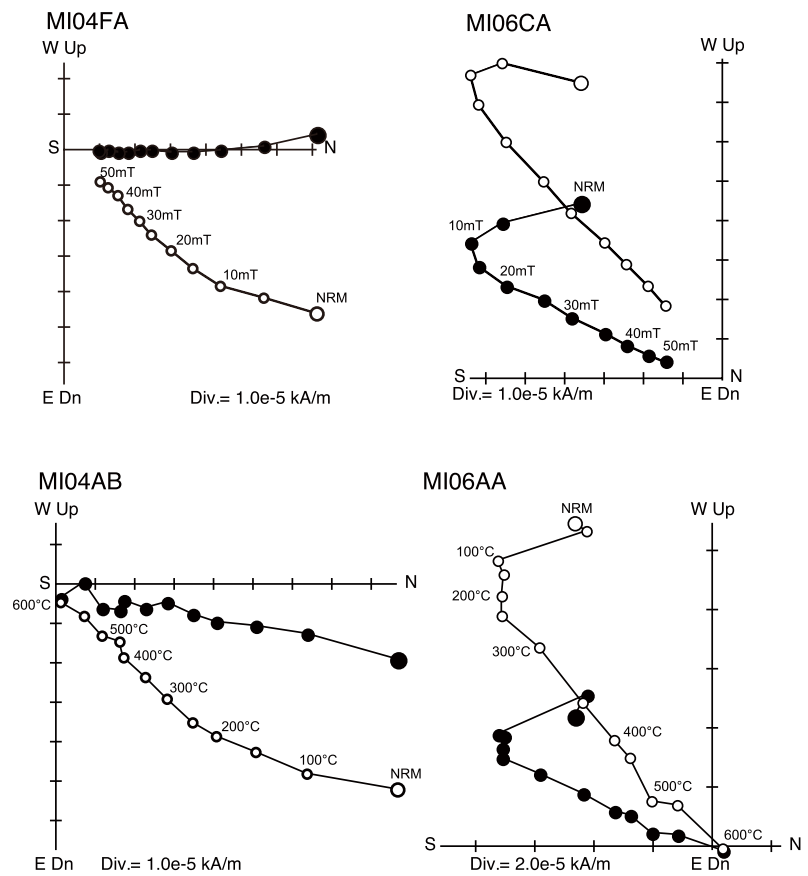

Fig. 3. Typical examples of vector endpoint diagrams for stepwise alternating field (upper) and thermal (lower) demagnetizations. Specimens within the same column are from the same site. Solid and open circles are horizontal and vertical components, respectively. In most cases, both kinds of demagnetization resulted in identical components and yield ChRMs.
向かって直線的に減衰する磁化成分は固有磁化成分 (ChRM; characteristic remanent magnetization)と呼ば れ，その試片が保持する最も初生的な磁化成分である. 本研 究では, 原点に向かって直線的に減衰する各消磁段階におけ る磁化成分を, 最低 5 ステップ以上用いて主成分分析を行 うことで ChRM を求めた.

3)測定結果 パイロット試片に対して施した段階交流消磁お よび段階熱消磁の代表例を Fig. 3 に示す. 図では上の段に 段階交流消磁の結果を, 下の段に段階熱消磁の結果を表示し た. 今回, ほとんどの試片において段階交流消磁および段階 熱消磁ともにChRM を抽出することができた. これらは段 階交流消磁では 20〜30 mT で二次磁化成分が除去され, 原 点に向かいほぼ直線的に消磁されていた. また段階熱消磁で は, 200 300 ${ }^{\circ} \mathrm{C}$ までに二次磁化成分が除去され， $500{ }^{\circ} \mathrm{C}$ 付近以上まで ChRM を担う磁化成分が保持されていた. 以 上より，これらの $\mathrm{ChRM}$ はキュリー温度が $500{ }^{\circ} \mathrm{C}$ 以上で あるチタン鉄鉱もしくは磁鉄鉱によって担われていると考え られる. またこれらのChRM は同じ採取地点においてよく 一致したため, 各地点における残りの試片については基本的 に段階交流消磁により ChRMの抽出を行った.

求められた ChRM が地層形成当時に獲得された初生磁化 であることを判断するため褶曲テストおよび逆転テストとい う 2 種類のフィールドテストを行った. 褶曲テストには 3 つ以上の ChRM が得られた地点における平均磁化方位と, それらの 95\%信頼円 $\left(\alpha_{95}\right)$ を用いた. これらは全て段階交流 消磁の結果である. また $\alpha_{95}$ が大きい場合 (本論文では $20^{\circ}$

Table 1. Site mean directions of ChRMs datermined during AF demagnetization (AFD) and other parameters used throughout the fold and reversals tests, and ChRMs determined during thermal demagnetization (THD) used throughout the reversals test. N; number of specimens; $\kappa$; Fisher precision parameter; $\alpha_{95} ; 95 \%$ confidence limit.

\begin{tabular}{|c|c|c|c|c|c|c|c|c|c|c|}
\hline \multirow{2}{*}{$\begin{array}{l}\text { Site } \\
\text { No. }\end{array}$} & \multirow{2}{*}{$\begin{array}{c}\text { Thickness } \\
(\mathrm{m})\end{array}$} & \multicolumn{2}{|c|}{ Bedding } & \multicolumn{2}{|c|}{ ChRM from THD. } & \multicolumn{5}{|c|}{ Site mean and confidence limit from AFD. } \\
\hline & & Strike & Dip & Dec. & Inc. & $\mathrm{N}$ & $\kappa$ & $\alpha_{95}$ & Dec. & Inc. \\
\hline MI16 & unknown & $74^{\circ} \mathrm{E}$ & $20^{\circ} \mathrm{S}$ & 218.7 & -57.7 & 3 & 88.0 & 13.2 & 213.5 & -53.5 \\
\hline MI12 & 480.5 & $70^{\circ} \mathrm{E}$ & $40^{\circ} \mathrm{N}$ & 172.4 & -48.8 & 3 & 59.7 & 16.1 & 190.1 & -67.9 \\
\hline MI07 & 475.9 & $79^{\circ} \mathrm{E}$ & $42^{\circ} \mathrm{N}$ & \multicolumn{2}{|c|}{ not detected } & 5 & 239.8 & 5.0 & 195.4 & -56.9 \\
\hline Ml13 & 452.2 & $72^{\circ} \mathrm{E}$ & $40^{\circ} \mathrm{N}$ & \multicolumn{2}{|c|}{ not detected } & 4 & 10.8 & 29.3 & 206.9 & -72.0 \\
\hline MI20 & 433.4 & $66^{\circ} \mathrm{E}$ & $42^{\circ} \mathrm{N}$ & 194.9 & -58.6 & 3 & 263.4 & 7.6 & 227.0 & -66.1 \\
\hline Ml19 & 424.0 & $73^{\circ} \mathrm{E}$ & $44^{\circ} \mathrm{N}$ & 190.0 & -44.1 & 3 & 440.4 & 5.9 & 202.3 & -58.6 \\
\hline MI21 & 402.6 & $78^{\circ} \mathrm{E}$ & $44^{\circ} \mathrm{N}$ & 188.6 & -49.2 & 3 & 385.2 & 6.3 & 195.8 & -56.6 \\
\hline MI06 & 333.3 & $79^{\circ} \mathrm{E}$ & $47^{\circ} \mathrm{N}$ & \multicolumn{2}{|c|}{ not detected } & 4 & 179.7 & 6.9 & 202.1 & -52.4 \\
\hline MI09 & 261.5 & $79^{\circ} \mathrm{E}$ & $50^{\circ} \mathrm{N}$ & 0.9 & 46.4 & 4 & 192.2 & 6.6 & -8.9 & 40.2 \\
\hline MI08 & 259.8 & $79^{\circ} \mathrm{E}$ & $50^{\circ} \mathrm{N}$ & -1.8 & 34.1 & 4 & 193.6 & 6.6 & 1.0 & 32.7 \\
\hline MI01 & 254.1 & $79^{\circ} \mathrm{E}$ & $47^{\circ} \mathrm{N}$ & 10.9 & 48.7 & 6 & 342.9 & 3.6 & 8.8 & 49.5 \\
\hline MI02 & 247.8 & $79^{\circ} \mathrm{E}$ & $47^{\circ} \mathrm{N}$ & -8.6 & 44.4 & 3 & 3145.5 & 2.2 & -8.0 & 45.8 \\
\hline MI03 & 241.0 & $79^{\circ} \mathrm{E}$ & $47^{\circ} \mathrm{N}$ & -9.1 & 57.1 & 4 & 211.2 & 6.3 & -9.0 & 48.2 \\
\hline MI04 & 239.1 & $79^{\circ} \mathrm{E}$ & $47^{\circ} \mathrm{N}$ & \multicolumn{2}{|c|}{ not detected } & 6 & 186.7 & 4.9 & 2.6 & 49.0 \\
\hline MI05 & 238.5 & $79^{\circ} \mathrm{E}$ & $47^{\circ} \mathrm{N}$ & \multicolumn{2}{|c|}{ not detected } & 6 & 52.0 & 9.4 & 17.8 & 44.2 \\
\hline MR24 & 180.0 & $79^{\circ} \mathrm{E}$ & $54^{\circ} \mathrm{N}$ & -1.8 & 36.8 & 4 & 336.2 & 5.0 & 2.1 & 33.3 \\
\hline MR23 & 169.0 & $79^{\circ} \mathrm{E}$ & $54^{\circ} \mathrm{N}$ & 1.8 & 36.9 & 3 & 83.8 & 13.5 & 6.4 & 33.6 \\
\hline MR22 & 161.0 & $84^{\circ} \mathrm{E}$ & $60^{\circ} \mathrm{N}$ & -4.7 & 15.1 & 4 & 44.3 & 14.0 & -3.4 & 18.5 \\
\hline MR21 & 145.0 & $84^{\circ} \mathrm{E}$ & $60^{\circ} \mathrm{N}$ & 14.5 & 43.1 & 3 & 793.2 & 4.4 & 11.7 & 39.0 \\
\hline MR20 & 132.0 & $84^{\circ} \mathrm{E}$ & $60^{\circ} \mathrm{N}$ & -4.2 & 52.6 & 4 & 520.2 & 4.0 & -3.9 & 49.3 \\
\hline MR10 & 110.0 & $74^{\circ} \mathrm{E}$ & $60^{\circ} \mathrm{N}$ & 8.7 & 35.2 & 3 & 68.3 & 15.0 & 7.7 & 31.1 \\
\hline MR15 & 84.0 & $74^{\circ} \mathrm{E}$ & $60^{\circ} \mathrm{N}$ & \multicolumn{2}{|c|}{ not detected } & 4 & 159.3 & 7.3 & -5.1 & 25.4 \\
\hline MR13 & 81.0 & $74^{\circ} \mathrm{E}$ & $60^{\circ} \mathrm{N}$ & \multicolumn{2}{|c|}{ not detected } & 3 & 28.2 & 23.6 & 209.4 & -36.0 \\
\hline MR12 & 79.0 & $74^{\circ} \mathrm{E}$ & $60^{\circ} \mathrm{N}$ & \multicolumn{2}{|c|}{ not detected } & 3 & 2.7 & 97.4 & 207.4 & -65.8 \\
\hline MR11 & 77.0 & $74^{\circ} \mathrm{E}$ & $60^{\circ} \mathrm{N}$ & \multicolumn{2}{|c|}{ not detected } & 5 & 27.7 & 14.8 & 199.8 & -32.9 \\
\hline MR05 & 57.0 & $84^{\circ} \mathrm{E}$ & $56^{\circ} \mathrm{N}$ & \multicolumn{2}{|c|}{ not detected } & 3 & 4.0 & 72.1 & 33.7 & 43.1 \\
\hline MR02 & 33.0 & $84^{\circ} \mathrm{E}$ & $56^{\circ} \mathrm{N}$ & \multicolumn{2}{|c|}{ not detected } & 3 & 13.1 & 35.6 & 197.7 & -59.9 \\
\hline MR01 & 29.0 & $76^{\circ} \mathrm{E}$ & $58^{\circ} \mathrm{N}$ & \multicolumn{2}{|c|}{ not detected } & 3 & 40.4 & 19.7 & 206.3 & -74.1 \\
\hline MR19 & 25.0 & $84^{\circ} \mathrm{E}$ & $60^{\circ} \mathrm{N}$ & \multicolumn{2}{|c|}{ not detected } & 4 & 31.2 & 16.7 & -7.8 & -16.5 \\
\hline MR18 & 17.0 & $84^{\circ} \mathrm{E}$ & $60^{\circ} \mathrm{N}$ & \multicolumn{2}{|c|}{ not detected } & 3 & 223.8 & 8.3 & -10.4 & 28.4 \\
\hline MR17 & 12.0 & $84^{\circ} \mathrm{E}$ & $60^{\circ} \mathrm{N}$ & 26.7 & 37.6 & 3 & 171.8 & 9.4 & 19.0 & 36.6 \\
\hline MR16 & 0.0 & $84^{\circ} \mathrm{E}$ & $60^{\circ} \mathrm{N}$ & -3.3 & 15.3 & 4 & 169.0 & 7.1 & -3.9 & 11.5 \\
\hline
\end{tabular}



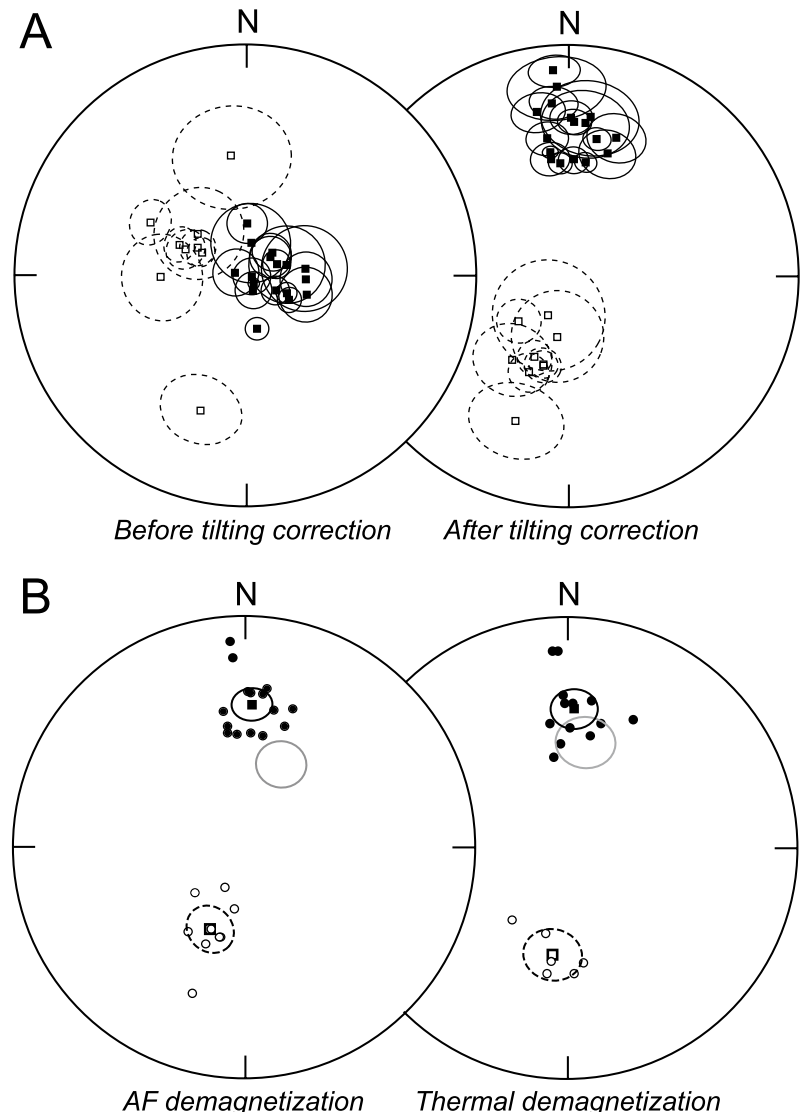

Fig. 4. Equal-area projections for A) the fold test and B) reversals test. Small solid and open circles indicate lower and upper hemisphere projections, respectively. Solid and dotted circles indicate the $95 \%$ confidence limit at each site projected on lower and upper hemispheres, respectively. A: The fold test using site mean directions of ChRMs obtained during AF demagnetization. The clustering is of directions improves after a tilting correction applied, suggesting that magnetic remanences were acquired prior to tilting of the strata. B: Reversals test using ChRMs obtained during AF (left) and thermal (right) demagnetization. Gray circles indicate antipodal reversed directions.

以上を基準とした)や，当時の地球磁場が地軸双極子磁場か ら大きく外れていた可能性が高い極性反転境界周辺の地点の データは, 褶曲テストには用いなかった. 褶曲テストに用い たデータを Table 1 に, 傾動補正前後のステレオネットプ ロットを Fig. 4A に示す.もしこれらの平均磁化方位が地 層の傾動前に獲得されていたならば，傾動補正後の磁化方位 が地軸双極子から推定される方向付近に集中し，傾動補正前 の磁化方位は地点ごとの地層の傾動に応じて様々な方向に向 くはずである. Fig. 4A では, 傾動補正前と比べて明らかに 傾動補正後の方が磁化方位の集中度が高くなっており，これ らの磁化方位が地層傾動前に獲得されたことを示す.

つづいて, 褶曲テストで用いた段階交流消磁による地点ご との平均磁化方位と, それらと同地点で得られたパイロット 試片の段階熱消磁から得られた ChRM(Table 1) を用いて 逆転テストを行った (Fig. 4B)，もし得られた ChRMに二 次磁化成分が全く含まれていなければ，正極性を示す
ChRM の分布は，逆極性のそれと対称的になるはずである. 今回の結果は, 段階交流消磁では正極性を示す ChRM の信 頼円と逆極性のそれを対称位置に移動したものとが完全に分 離しており，逆転テスト不合格であることを示した．段階熱 消磁の結果では, 両者の信頼円は重なっているが，相手方の 平均磁化方位を含んではいない. この結果は, McFadden and McElhinny (1990)による逆転テスト判定で不合格と なった. 今回の結果では, 調査地域の緯度から見た地軸双極 子による伏角 (約 $52^{\circ}$ ) と比へ, 正極性の伏角が浅く, 逆極性 の伏角が深くなっている. このことは, 今回の試料採取地域 の地層は北傾斜が卓越していることを考慮すると, 得られた ChRM 中に地層傾動後の正磁極期中に獲得された二次磁化 が若干残っていることを示す. しかしそれらの二次磁化成分 は磁化極性を覆すほどの大きさではないため, 古地磁気層序 構築に必要な極性判別をする上で問題はないと判断した.

今回得られた ChRM と研究地域の緯度から VGP (virtual geomagnetic pole)の緯度を算出し, その值が $45^{\circ}$ 以上の 時は正極性, $-45^{\circ}$ 以下の時は逆極性, $-45^{\circ} \sim 45^{\circ}$ の間を 示すときは中間極性として極性判別を行った. 極性判別の結 果を Fig. 6 の岩相柱状図の右側に示す.この結果は, 層準 約 28〜84 m の間と約 $330 \mathrm{~m}$ より上位の層準が逆磁極帯で あり, それ以外の層準が正磁極帯であることを示す．極性反 転境界付近の磁化方位は中間極性を示しており, これらは磁 場反転途中の地磁気を反映したものと考えられる. 中部の正 磁極帯から上部の逆磁極帯の間の逆転境界は, 正磁極を示す 最上位の試料 MI17 (318 m) と逆磁極を示す最下位の MI06 (333.3 m) の間に存在し，おそらく中間極性を示す MI18 (328.3 m)の近傍と考えられる.

4) 古地磁気極性対比 古地磁気極性デー夕, 酸素同位体測定 結果および亀尾ほか (2003)によって同ルートで確認された 石灰質ナノプランクトン化石基準面を岩相柱状図とともに Fig. 6 に示す. 小竹ほか (1995)および亀尾ほか(2003)によ る当該地域における古地磁気一微化石層序の検討により, す でに上部の逆磁極帯が Matuyama 逆磁極帯に, 下部の正磁 極帯が Gauss 正磁極帯にそれぞれ相当することは報告され ているが, 下部の正磁極帯中に確認された逆磁極帯について は, 本論文が最初の報告となる. 布良層模式地である布良海 岸における研究では, 古地磁気および微化石層序の検討か ら, 小竹ほか (1995)において Kaena 逆磁極亜帯が, また岡 田ほか(2006)において Kaena および Mammoth の両逆磁 極亜帯の存在が確認されている. 本論文における当該層準の 微化石層序はまだ検討されていないが, 古地磁気試料の採取 密度から考えて, 当該逆磁極帯の上位に別の逆磁極帯がある と考えることは難しい. よってこの逆磁極帯は Kaena 逆磁 極帯に相当すると考えられる.

\section{2. 酸素同位体層序}

1)試料採取および処理 酸素同位体測定のための底生有孔虫 化石抽出用試料の採取は古地磁気試料同様に，シルト岩およ び砂質シルト岩層を対象に行った. 露頭表面や割れ目等に 沿つて風化している部分を露頭から取り除いて新鮮な面を露 出させ, 各層準から乾燥重量にして約 200～300 g に相当す 
Table 2. Oxygen isotope data obtained during this study; results for NM and UD are given in part A and CM in part B. Abbreviations for benthic foraminifers used in this study are as follows: Bo, Bolivinita quadrilatera; Uh, Uvigerina hispidocostata; Up, U. proboscidea; Bu, Bulimina spp.; Ca, Cassidulina subglogbosa; Ci, Cibicidoides wuellerstorfi. Average values are derived from values adjusted to $U$. hispidocostata using the inter-species calibration results shown in Fig. 5 and Table 3.

\begin{tabular}{|c|c|c|c|c|c|c|c|}
\hline \multirow{2}{*}{ Site No. } & \multirow{2}{*}{$\begin{array}{l}\text { Thickness } \\
(\mathrm{m})\end{array}$} & \multicolumn{5}{|c|}{ Benthic foraminifera species } & \multirow{2}{*}{$\begin{array}{r}\text { Average } \\
\text { value }(\% \circ\end{array}$} \\
\hline & & Bo & Uh & $\mathrm{Ca}$ & $\mathrm{Ci}$ & $\mathrm{Bu}$ & \\
\hline NM37 & 265.3 & 3.30 & 3.29 & & & & 3.33 \\
\hline NM36 & 262.4 & 3.23 & 3.36 & & & & 3.33 \\
\hline UD13 & 261.5 & 3.31 & 3.29 & 3.30 & 2.65 & & 3.33 \\
\hline NM35 & 259.8 & 3.36 & 3.46 & & & & 3.44 \\
\hline UD12 & 257.5 & 3.38 & 3.45 & & & & 3.45 \\
\hline \multirow[t]{2}{*}{ NM34 } & 257.0 & & 3.30 & & & & 3.33 \\
\hline & & 3.31 & 3.30 & 3.28 & & & \\
\hline \multirow[t]{2}{*}{ UD11 } & 255.5 & 3.30 & & 3.14 & & & 3.33 \\
\hline & & 3.27 & & & & & \\
\hline NM33 & 254.1 & 3.52 & 3.48 & & & & 3.53 \\
\hline UD10 & 251.5 & 3.30 & & & & & 3.33 \\
\hline NM32 & 251.2 & 3.63 & 3.61 & & & & 3.65 \\
\hline NM29 & 247.8 & & 2.77 & & & & 2.80 \\
\hline NM28 & 246.9 & 4.02 & 4.11 & & & & 4.09 \\
\hline UD09 & 246.5 & 3.93 & 3.83 & 3.91 & 3.37 & & 3.95 \\
\hline UD08 & 244.5 & 3.90 & 3.93 & 3.97 & 3.26 & & 3.95 \\
\hline NM22 & 242.9 & & & 3.82 & & & 3.85 \\
\hline NM21 & 241.0 & 3.67 & 3.78 & & & & 3.76 \\
\hline NM20 & 239.1 & 3.73 & 3.68 & & 3.04 & & 3.73 \\
\hline UD07 & 238.5 & 3.79 & 3.77 & 3.86 & & 3.81 & 3.85 \\
\hline UD06 & 225.5 & 3.44 & 3.71 & 3.68 & 3.05 & & 3.66 \\
\hline NM15 & 223.0 & 3.54 & 3.43 & & 2.89 & & 3.53 \\
\hline UD05 & 217.5 & 3.12 & & & 2.50 & 3.13 & 3.18 \\
\hline UD04 & 214.5 & 3.13 & & 3.14 & & 3.21 & 3.21 \\
\hline UD03 & 208.5 & 3.52 & & & & & 3.55 \\
\hline UD02 & 204.5 & 3.29 & & & & & 3.32 \\
\hline NM7 & 184.2 & 3.10 & & & & & 3.13 \\
\hline NM6 & 182.1 & 3.27 & & & 2.40 & & 3.18 \\
\hline UD01B & 180.5 & & & 3.00 & & & 3.03 \\
\hline UD01A & 179.5 & 3.10 & & 3.13 & 2.56 & & 3.17 \\
\hline UD00 & 167.5 & 3.76 & 3.90 & 3.85 & & 3.71 & 3.85 \\
\hline NM38 & 160.2 & 3.33 & & & & & 3.36 \\
\hline NM41 & 148.5 & 3.73 & & & & & 3.76 \\
\hline NM42 & 146.0 & & & & & 3.50 & 3.53 \\
\hline NM43 & 143.9 & 3.26 & & & & & 3.29 \\
\hline NM44 & 140.2 & & & & & 3.31 & 3.34 \\
\hline NM45 & 136.3 & & & & 2.55 & & 3.21 \\
\hline NM46 & 132.0 & 3.30 & & & & & 3.33 \\
\hline NM47 & 128.5 & & & & & 3.51 & 3.61 \\
\hline NM48 & 125.4 & & & & & 3.32 & 3.42 \\
\hline NM49 & 121.5 & & & & 2.66 & 3.41 & 3.41 \\
\hline NM50 & 119.0 & & & & & 3.49 & 3.59 \\
\hline NM51 & 116.5 & & 3.39 & & & & 3.42 \\
\hline
\end{tabular}

\begin{tabular}{|c|c|c|c|c|c|c|}
\hline \multirow{2}{*}{ Site No. } & \multirow{2}{*}{$\begin{array}{l}\text { Thickness } \\
\text { (m) }\end{array}$} & \multicolumn{4}{|c|}{ Benthic foraminifera species } & \multirow{2}{*}{$\begin{array}{c}\text { Average } \\
\text { value }(\% o\end{array}$} \\
\hline & & Bo & Uh & Up & $\mathrm{Bu}$ & \\
\hline CM01 & 480.5 & & & & 3.80 & 3.76 \\
\hline $\mathrm{CMO3}$ & 475.9 & & & & 3.37 & 3.33 \\
\hline CM04 & 469.7 & & & & 3.13 & 3.10 \\
\hline CM05 & 467.8 & & & & 3.47 & 3.44 \\
\hline CM06 & 465.2 & & & & 3.51 & 3.47 \\
\hline CM07 & 461.6 & 3.56 & & 3.56 & & 3.59 \\
\hline CM08 & 458.7 & & & & 3.35 & 3.31 \\
\hline CM09 & 456.8 & & & & 3.23 & 3.19 \\
\hline CM10 & 454.0 & 3.49 & & 3.48 & & 3.52 \\
\hline CM11 & 452.2 & 3.74 & & 3.52 & & 3.66 \\
\hline CM12 & 448.8 & & & & 4.08 & 4.04 \\
\hline CM13 & 436.9 & & & & 3.80 & 3.76 \\
\hline CM14 & 433.4 & & & & 3.57 & 3.53 \\
\hline CM15 & 431.3 & & & & 3.36 & 3.33 \\
\hline CM16 & 426.9 & & & & 3.01 & 2.97 \\
\hline CM17 & 424.0 & & & & 2.95 & 2.91 \\
\hline CM20 & 399.2 & & & & 3.74 & 3.70 \\
\hline CM21 & 392.4 & & & & 3.29 & 3.26 \\
\hline CM22 & 390.2 & & & & 3.42 & 3.38 \\
\hline CM23 & 388.4 & & & & 3.61 & 3.57 \\
\hline CM24 & 384.4 & & & & 3.97 & 3.93 \\
\hline CM25 & 371.8 & 4.35 & & & & 4.38 \\
\hline CM26 & 367.8 & 3.97 & & & & 4.00 \\
\hline CM27 & 365.9 & 3.61 & & & & 3.64 \\
\hline CM28 & 363.7 & & & & 3.34 & 3.30 \\
\hline CM29 & 360.7 & & & & 3.14 & 3.10 \\
\hline CM30 & 359.5 & & & & 3.15 & 3.11 \\
\hline CM31 & 356.9 & & & 3.23 & & 3.26 \\
\hline CM32 & 354.4 & 3.17 & & 3.27 & & 3.25 \\
\hline CM33 & 352.2 & & & & 3.33 & 3.29 \\
\hline CM34 & 350.7 & & 3.47 & & & 3.50 \\
\hline CM35 & 348.3 & & 3.58 & & & 3.61 \\
\hline CM36 & 345.7 & 3.65 & & & & 3.68 \\
\hline CM38 & 341.0 & 3.48 & & & & 3.51 \\
\hline CM39 & 333.3 & 3.15 & & & & 3.18 \\
\hline CM42 & 314.4 & 3.72 & & & & 3.75 \\
\hline CM43 & 312.9 & 3.83 & & & & 3.86 \\
\hline CM55 & 275.2 & 3.77 & & 3.80 & & 3.81 \\
\hline CM56 & 273.2 & 3.73 & & & & 3.76 \\
\hline CM57 & 270.7 & 3.37 & & & & 3.40 \\
\hline CM58 & 266.2 & 3.32 & & & & 3.35 \\
\hline CM60 & 263.5 & 3.13 & & & & 3.16 \\
\hline CM61 & 261.0 & 3.35 & & & & 3.38 \\
\hline CM62 & 258.5 & 3.34 & & & & 3.37 \\
\hline CM63 & 256.3 & 3.40 & & & & 3.43 \\
\hline CM64 & 253.1 & 3.36 & & & & 3.39 \\
\hline CM65 & 245.7 & & 3.75 & & & 3.78 \\
\hline CM66 & 243.1 & 3.50 & & & & 3.53 \\
\hline CM59 & 240.7 & 3.94 & & & & 3.97 \\
\hline
\end{tabular}

る岩石試料を採取した. 今回の研究対象である $3 \mathrm{Ma}$ 前後の 時期に卓越した氷期一間水期サイクルの変動周期はおよそ 4 万 1 千年であると考えられている(Tiedemann et al., 1994)．この酸素同位体変動を復元するためには，1 周期あ たり 8 点(約 5000 年間隔)で試料を採取すれば，最低限の精 度で変動を検討することができる. そこで, 南朝夷層の平均 堆積速度である $70 \mathrm{~cm} / \mathrm{kyr}$ (亀尾ほか, 2003)をもとに, 5000 年 $=3.6 \mathrm{~m}$ の間隔を試料採取の目安とした. 同位体測 定用試料は，シルト岩および砂質シル卜岩層における層厚間 隔が $3 \mathrm{~m}$ 程度なるように採取したが，露頭欠如のため 3 力 所で層厚 $4 \mathrm{~m}$ 以上の間隙ができてしまった(下位から, 340 350 m, 373-377 m, 435-441 m). このほか, 試料は採取 したものの, 底生有孔虫化石の産出数が極端に少なく, 同位 体測定を行うことができなかった層準が 3 力所(下位から
190-200 m, 225-235 m, 245-320 m)あつた.

採取試料は実験室において 2 3 cm 角程度の大きさに砕 いた後ビーカーに入れ，約 $60^{\circ} \mathrm{C}$ に設定したオーブンで 1 〜2 日乾燥させ, 乾燥重量を測定した. 本研究では, 同位体 測定への影響を最低限にするため, 岩石粉砕のための薬品処 理や加熱処理は行わず，家庭用ミキサーに試料と水を加えて 機械的に粉砕した. その後 250 メッシュのふるいで水洗し, 残留物を約 $60{ }^{\circ} \mathrm{Cに}$ 設定したオーブンで 1 ～ 2 日乾燥させた. 乾燥させた試料を 32 メッシュのふるいにかけ，そこを通過 した試料から Isodynamic Separator を用いて磁性鉱物を含 む粒子を取り除いた，磁性鉱物を含む粒子が除去された試料 を 150 メッシュのふるいにかけ, 残留物から底生有孔虫化 石を双眼実体顕微鏡下で拾い出した.

2)測定方法 本研究では, 同位体測定の前処理・測定ともに 


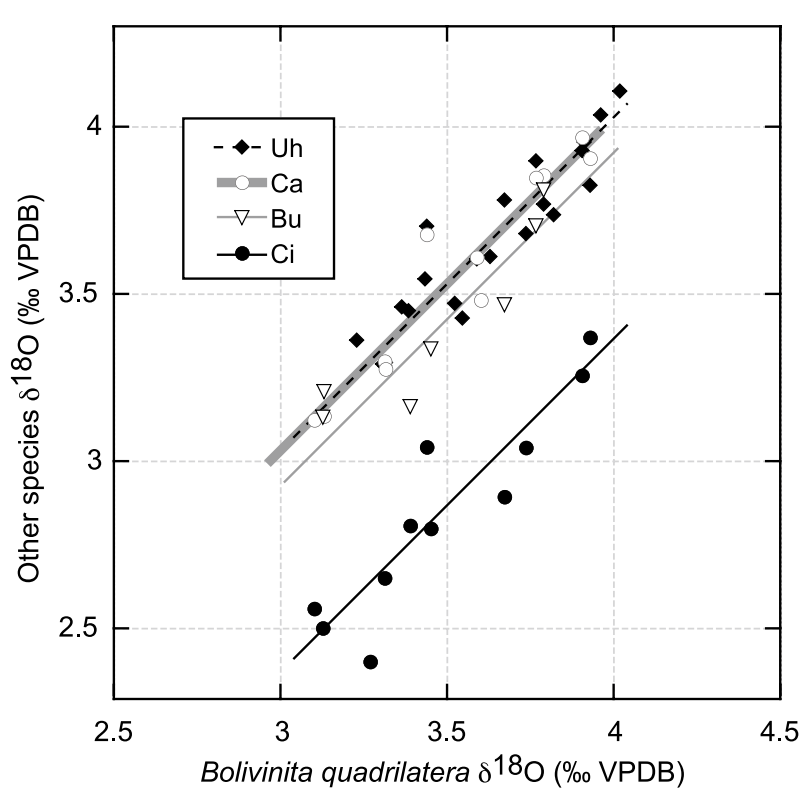

Fig. 5. Inter-species calibration for $\delta^{18} \mathrm{O}$ values of benthic foraminifers analyzed during this study. Bolivinita quadrilatera $\delta^{18} \mathrm{O}$ values are plotted on the horizontal axis, whereas $\delta^{18} \mathrm{O}$ values of other species yielded from the same site are plotted on the vertical axis. Regression lines fitted using linear functions with a 45-degree gradient are shown for each species. Abbreviations for benthic foraminifers are shown in the caption for Table 2. Note that the regression lines for $\mathrm{Uh}$ and $\mathrm{Ca}$ overlap.

Table 3. Averaged $\delta^{18} \mathrm{O}$ offset values for various species of benthic foraminifer compared with Uvigerina hispidocostata.

\begin{tabular}{cc}
\hline $\begin{array}{c}\text { Benthic foraminifera } \\
\text { species }\end{array}$ & $\begin{array}{c}\text { Difference (\%o) from } \\
\text { Uvigerina hispidocostata }\end{array}$ \\
\hline Bolivinita quadrilatera & -0.03 \\
Bulimina spp. & -0.10 \\
Cassidulina subglobosa & 0.00 \\
Cibicidoides wuellerstorfi & -0.66 \\
\hline
\end{tabular}

高知大学海洋コア総合研究センターにて行つた．測定に使用 した底生有孔虫化石は, Bolivinita quadrilatera, Bulimina spp., Uvigerina proboscidea, Uvigerina hispidocostata, Cassidulina subglogbosa, Cibicidoides wuellerstorfiの 6 種 (Bulimina のみ複数種混在)である. 本研究 では各底生有孔虫種の略記号として，それぞれ $\mathrm{Bo}, \mathrm{Bu}$, $\mathrm{Up}, \mathrm{Uh}, \mathrm{Ca}, \mathrm{Ci}$ と記した. 測定には 1 試料につき乾燥重 量で $120 \sim 160 \mu \mathrm{g}$ (3〜7 個体に相当)の底生有孔虫化石を用 いた．測定の前処理は以下の通りである．秤量した底生有孔 虫化石をバイアル瓶に入れ，メタノールを加えて約 30 秒程 度の超音波洗浄を行い，上澄夕液を捨てる．その後針金を用 いてバイアル瓶の中の底生有孔虫化石を大まかに砕き，再び メ夕ノールを加え約 5 秒程度の超音波洗浄を行い，上澄み 液を捨てるという作業を 3 回繰り返す。その後, 数時間乾 燥させ同位体測定用の最終試料とした. 測定にはジャスコイ ンターナショナル株式会社製の安定同位体質量分析装置
Isoprime Multiprep を使用した. 測定值はカルサイトの酸 素・炭素同位体比標準である V-PDB (Vienna Peedee belemnite) との酸素同位体比の差を $\delta^{18} \mathrm{O}$ 值として千分率 $(\%)$ で表した. 同位体測定の正確度を高めるため, カルサイト標 準試料(NBS19) を測定の最初と最後だけではなく測定試料 の合間にも測定して測定值の較正を行った. 全 NBS19 測 定における $\delta^{18} \mathrm{O}$ 值の標準偏差は $0.06 \%$ となり, この值を本 研究における $\delta^{18} \mathrm{O}$ 值の測定精度とした.

3 )測定結果 $\delta^{18} \mathrm{O}$ 測定の全結果を Table $2 \mathrm{~A}$ (沢ルート)およ び Table 2B (林道ルート)に示す.ここでは, 同一層準で複 数の測定がなされた場合は全ての值を表示した. また一つの 層準で複数種の測定值がある場合は, 次に述べる種間較正の 結果を用いることで, 全ての種の $\delta^{18} \mathrm{O}$ 值を, LR04 を含め 一般的に底生有孔虫化石の $\delta^{18} \mathrm{O}$ 值の基準とされている Uvigerina 属の值に換算した上で, 層準ごとの平均值を算出し た.

底生有孔虫化石は, 同一層準から産出しても, 種により酸 素同位体の值がわずかに異なることが知られている (Shackleton and Hall, 1984). したがって, 酸素同位体測定に当 たっては，全層準で同じ種を用いることが望ましい．しか し, 海底表層において生息する底生有孔虫の種組成は, 地層 堆積当時の海底面の環境等により変動するため, 産出する卓 越種が層準によって大きく異なることが多い. 本研究おいて も層準により卓越種が変化したため, 単一種での測定はでき なかった. Shackleton and Hall(1984)ではこの問題を解 決するために, 異なる底生有孔虫種の間における酸素同位体 值の差を求め, Uvigerina peregrina の值に補正すること で同位体カーブを描いた. 本研究で検討された種は, 彼らに よって報告された種とは一部を除き異なった. したがって, 同一層準で確認された全ての底生有孔虫種の同位体測定を行 うことで，独自に種間較正を試みた.

Fig. 5 は, 横軸に本研究における卓越種である Bolivinita quadrilatera $の \delta^{18} \mathrm{O}$ 值を, 縦軸にはそれと同一試料中にお いて産出した他の底生種の $\delta^{18} \mathrm{O}$ 值をプロットしたものであ る. ここでは種間較正の精度を高めるため, 布良層の測定 デー夕に，上位層である畑層における測定デー夕を加えた. 今回の結果では, 全ての種において傾きが $45^{\circ}$ となるよう な直線に沿ってデー夕点が分布していることから，種による $\delta^{18} \mathrm{O}$ の差は， $\delta^{18} \mathrm{O}$ の值によらず一定であることが示された. これより, 種ごとに傾きが $45^{\circ}$ となるような回帰直線を求 めることで基準となる Uvigerina hispidocostata との差を 算出した. その結果を Table 3 に示す. Uvigerina proboscidea に関しては, 布良層模式地で行った同様の研究(岡田 ほか, 2006)で U. hispidocostata との差が見られないこと が報告されているため，本論文では両者を同等にあつかった. Shackleton and Hall(1984)では, Cibicidoides wuellerstorf の $\delta^{18} \mathrm{O}$ 值から Uvigerina spp. のそれを引いた值が-0.64\% となっており, 本研究の結果である $-0.66 \%$ と測定誤差の 範囲で一致する.

基準值に換算した $\delta^{18} \mathrm{O}$ 值の層準ごとの平均值を用いて描 いた酸素同位体カーブを Fig. 6 に示す.カーブは 4.4〜 


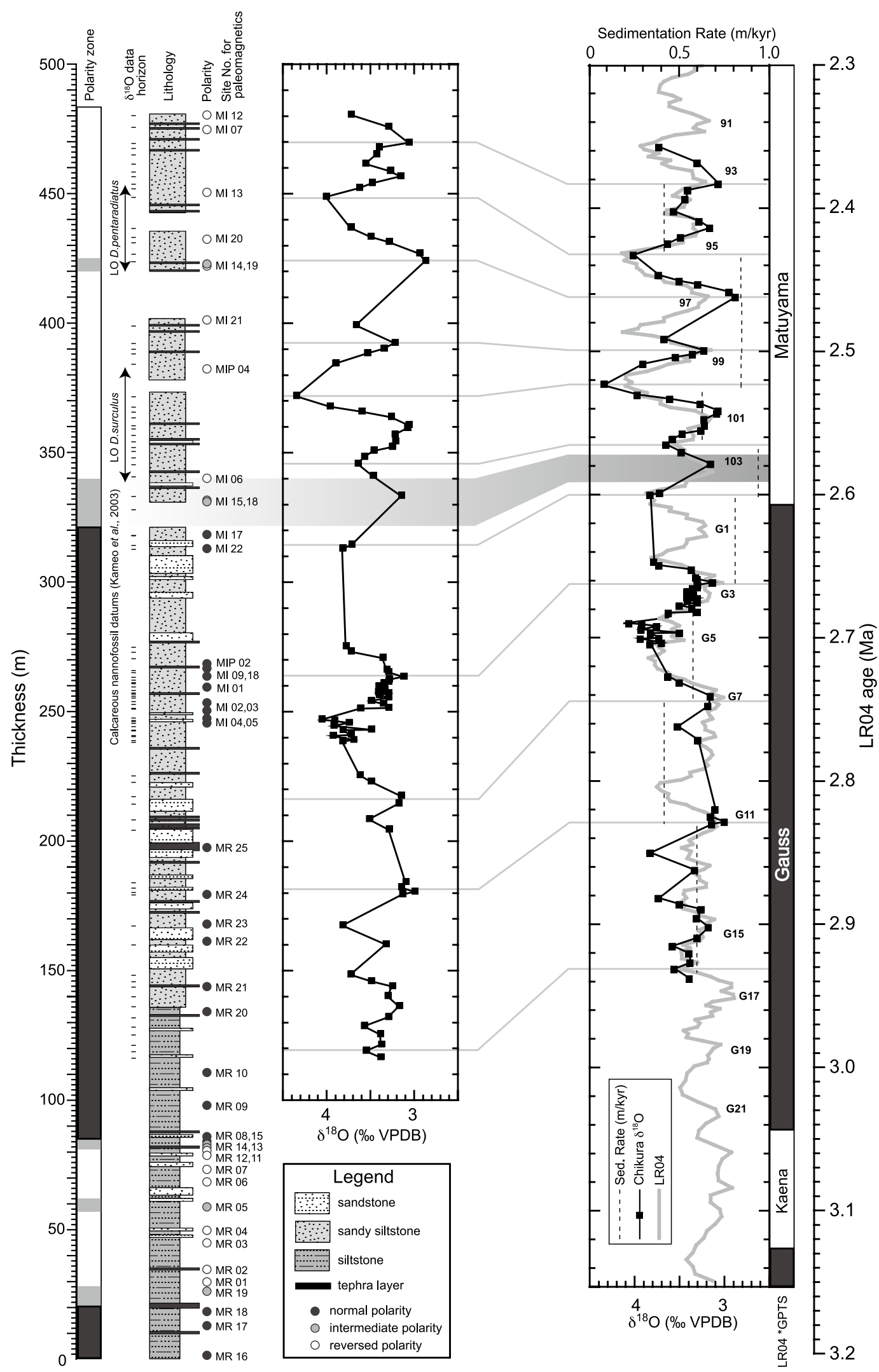

Fig. 6. Magnetostratigraphy, oxygen isotopic stratigraphy, and an age model of the middle section of the Chikura Group. The left vertical scale of the diagram indicates thickness of the sequence as measured from the lowermost sampling horizon. The right vertical scale indicates the LR04 age (Lisiecki and Raymo, 2005). Gray lines between oxygen isotope curves defined by thickness and age indicate the tie points used for construction of the age model. Broken lines within the age-scaled isotopic curve diagram indicate average sedimentation rates between tie points. *GPTS: Geomagnetic Polarity Time Scale. 
3.0\%の間を変動しており，これは LR04の変動範囲とほぼ 一致する.

\section{議論}

本論文の目的である「基準層序の提供」は，千倉層群からで きるだけ多くの全球的な層位学的指標(磁気極性反転境界・ 酸素同位体ステージ・生層序基準面等)を認定するとともに, それらの間にある層位学的関係を精度良く決定することであ る.これにより，千倉層群における任意の層準の年代を正確 に知ることが可能となる年代モデルを構築することができ る，千倉層群における酸素同位体カーブと酸素同位体標準 カーブとの対比に当たっては，標準カーブとして何を用いる かを決める必要がある. 近年, 鮮新統一更新統における酸素 同位体標準カーブとして幅広く用いられているLR04 (Lisiecki and Raymo, 2005) は, 57 本 (2.5 Ma 周辺では 24 本)の深海底堆積物コアから得られた底生有孔虫化石の酸 素同位体記録のスタックカーブで，コア採取地点は全球的に 広く分布している．またスタッキングに当たつては，それぞ れの記録の平均值や分散を規格化することなく，単純な算術 平均を用いているため, 得られたスタックカーブの $\delta^{18} \mathrm{O}$ 值 は, 当時の海水の $\delta^{18} \mathrm{O}$ 值と, 全球的に平均化された深層水 温とを反映したものとなっていて，地域的な差異が排除され たものとなっている. 一方, 2008 年の国際層序委員会 (International Commision on Stratigraphy; ICS) で最新の標 準年代スケールとして採用された GTS 2008 (Gradstein et al., 2008; Ogg et al., 2008 等)では，基本的な年代值や年 代モデルについて GTS 2004 (Gradstein et al., 2005) を踏 襲しており，鮮新統-更新統の底生有孔虫化石の酸素同位体 カーブとして, 西赤道大西洋スタック (ODP Sites 925 929) および東赤道太平洋スタック (ODP Sites 846 \& 849) が用いられている(Lourens et al., 2005a)。これらはいず れも局所的な值を代表したものであり，地域的な水温変化の 影響が残っていると考えられる。

LR04 の年代モデルおよび GTS2004 で年代モデルとし て用いられた ATTNS (astronomically tuned Neogene time scale) 2004 (Lourens et al., 2005a)のいずれにおいて も，年代モデル作成には天文年代較正が行われており，両者 とも基礎となる軌道要素解として La93 (Laskar et al., 1993）を用いている. このため両者の間に大局的な差異はな い. しかし年代較正方法が異なっているため，両者の酸素同 位体カーブの間には明らかな位相差が見られる. 現時点でど ちらが正しいか判断することはできないが，両者を混在して 扱うことはできない，本論文では，対比に用いる標準カーブ として，局所的な影響が排除された LR04 を用いることと した．だだし算出される年代值は，GTS 2004 で用いられ た ATTNS2004 で較正された年代值と最大で $20 \mathrm{kyr}$ 程度 異なる可能性がある.

Matuyama/Gauss 境界周辺における千倉層群産底生有孔 虫化石から得られた $\delta^{18} \mathrm{O}$ 值は LR04 とほぼ同じ值を示す。 このことは, 布良層の堆積水深がグローバルな平均深層水温 を示すほど十分な深さ (少なくとも 1000～2000 m 以深)で
あったことを意味する.これは本層準における底生有孔虫化 石の群集解析による古水深が $2000 \mathrm{~m}$ 前後であった (小竹, 1989; 小竹ほか, 1995) とされることと調和的である. した がって, 本論文における千倉層群の $\delta^{18} \mathrm{O}$ 值は, LR04 カー ブの振幅や形態のみならず，ピークやトラフの位置における $\delta^{18} \mathrm{O}$ の絶対值もよく一致するものとして対比を行った.

Matuyama/Gauss 境界より上位の層準に関しては, $\delta^{18} \mathrm{O}$ 值の振幅が大きく, また大きな測定層準の欠落も少ないの で，対比は比較的容易である．また同層準で認定された石灰 質ナノ化石基準面(亀尾ほか, 2003) は, ATNTS2004 に較 正された基準面年代表(Lourens et al., 2005b)によると, LO Discoaster pentaradiatus が 2.39〜2.51 Ma を, LO D. surculus が 2.49〜2.54 Ma を示し, 本研究の年代と矛 盾しない. 一方, Matuyama/Gauss 境界より下位について は測定層準の欠落が多く, 対比に正確さを欠く. 275 $315 \mathrm{~m}$ の欠落部の下位では, 250 270 m にまたがる同位 体カーブのピークと, その直下の 238〜248 m にかけて比 較的小さな同位体カーブのピークが連結している.この形状 は, LR04 における MIS (marine isotope stage; 海洋同位 体ステージ) G3 および G5 とよく一致する上, 周辺に類似 する波形パターンをもつ同位体カーブが存在しないことか ら，これらは MIS G3 および G5 に対比される可能性が高 いと考えられる. 次の大きな測定欠落層準の直下 $(180 \mathrm{~m}$ 付 近) は周辺層準と比べて最も軽い約 $3.2 \%$ という $\delta^{18} \mathrm{O}$ 值を示 しており, MIS G9 もしくは G11 の両方に対比可能である. 本論文では, $180 \mathrm{~m}$ 付近の層準を, $\delta^{18} \mathrm{O}$ 值が近い $\mathrm{G} 11$ に 対比されると判断した. それより下位の同位体カーブは振幅 が $0.6 \%$ 前後と小さく, 間水期のピーク值も $3.2 \%$ 以上であ ることから，少なくとも $3.0 \%$ 以下の值を持つ MIS G17 よ りも上位に対比されるはずである. 本論文では $\delta^{18} \mathrm{O}$ 值が類 似することより，150 m より下位の層準を MIS G14〜 G16 に対比した. 以上より, 計 10 点の同位体カーブ対比点を設 定し, 古地磁気層序と矛盾しない年代モデルを構築した (Table 4, Fig. 6).

ここで本論文の年代モデルより算出される Matuyama/ Gauss 境界の層位学的位置に注目すると, 境界部分の範囲 は $2.587 \pm 0.008 \mathrm{Ma}$ の間に相当し，間水期である MIS 103 に対応している.さらに中間極性が得られた MI18 層 準 $(328.3 \mathrm{~m})$ 付近に真の境界があるとするならば, 逆転境界 はまさに MIS 103 のピーク付近に対応する. しかし LR04 年代に較正された Matuyama/Gauss 境界の年代值は 2.608 Ma で, 水期である MIS 104 のトラフ付近に対応する (Lisieski and Raymo, 2005)ことから, 本論文の結果とは 矛盾する. LR04 における Matuyama/Gauss 境界より上位 の磁気逆転境界位置の決定には, 計 8 つの ODP サイトにお ける古地磁気・酸素同位体記録が用いられており，信頼性は 高いといえる.つまりこれらの深海底コアでは, 実際に MIS 104 付近で Matuyama/Gauss 境界が記録されている ことを意味する. 一方, ATNTS2004で用いられている, 腐泥とマールの互層からなるイタリア陸上セクションでは, Matuyama/Gauss 境界をMIS 103 に対応させている 
Table 4. Age model for the oxygen isotope record determined during this study. *indicates values from Lisiecki and Raymo (2005).

\begin{tabular}{cc}
\hline $\begin{array}{c}\text { Thickness } \\
(\mathrm{m})\end{array}$ & $\begin{array}{c}\text { LR04* age } \\
(\mathrm{Ma})\end{array}$ \\
\hline 470.0 & 2.383 \\
449.0 & 2.433 \\
423.5 & 2.463 \\
392.3 & 2.500 \\
371.8 & 2.524 \\
345.9 & 2.565 \\
313.1 & 2.600 \\
263.4 & 2.662 \\
217.0 & 2.742 \\
180.8 & 2.828 \\
118.6 & 2.932 \\
\hline
\end{tabular}

(Lourens et al., 1996). 両者の違いはどこからくるのであ ろうか?

堆積物が持つ残留磁化が, 実際には堆積面ではなく堆積物 中で徐々に獲得されることは古くから指摘され，この状況を 特に意識した磁化獲得機構として「後堆積残留磁化」 (pDRM; post-depositional remanent magnetization) と いう用語がある(Kent, 1973 等). 堆積直後の磁性粒子は, 堆積物中の間隙率が高いため自由に動ける. しかし, 埋積と ともに圧密効果により間隙率が減少し, 磁性粒子の方向が 徐々に固定され pDRMが獲得される(例えば Hyodo, 1984). なお, 平均的な磁化が獲得される深度という意味に おいて磁化獲得深度 (lock-in depth) という用語が広く用い られている.

これまで実際の磁化獲得深度は, 最後の磁場反転である Brunhes/Matuyama 境界の記録と酸素同位体等その他の環 境指標とを対比することで求められてきた，例えば，深海底 堆積物コアにおいては, 約 $16 \mathrm{~cm}$ (deMenocal et al., 1990), $15 \mathrm{~cm}$ (Suganuma et al., 2010), 房総半島上総層 群の塊状シルト岩では $42 \mathrm{~cm}$ (Okada and Niitsuma, 1989)や $21 \mathrm{~cm}$ (Tsunakawa et al., 1999) という磁化獲得 深度が報告されている. 一方 Tauxe et al.(2006) は, 塩分 が水中に添加されると, 水中を落下する粒子が凝集すること に着目し, 塩水中での再堆積実験を行った. その結果, 実際 の海底堆積物は, 海水中を粒子がコロイド状の塊となり降下 するため, 細粒の磁性粒子は他の粗粒粒子に吸着しており, 間隙率のいかんに関わらず堆積直後に磁化が固定され得るこ とを実験的・理論的に示した. その後, Liu et al. (2008)は, 信頼できる同位体カーブと古地磁気記録を同時に提供するコ アを厳選し, それらを比較することで, 磁化獲得深度を再計 算した. その結果, 深海底コアにおける磁化獲得深度が最大 で $20 \mathrm{~cm}$ 程度であることを示し, その深度が生物攪乱の影 響が及ぶと一般的に考えられる深度とほぼ一致することを指 摘した. では生物攪乱はどの深度まで影響を与えると考えら れているのであろうか. Ekdale et al.(1984)は, 大西洋の 様々な海域から採取された海底表層試料の観察から，表層堆 積物が 3 層に区分されることを報告した。 その 3 層とは上 位から, 均質に混ぜられた混合層 (Mixed Layer), 徐々に
生物攪乱の影響が無くなる漸移層 (Transition Layer), そ して生物攪乱の影響が無い歴史層(Historical Layer)であ る. これらの海底面からの深度は, 混合層/漸移層境界が 5-8 cm, 漸移層／歴史層境界が 20-35 cm と報告されてい る (Berger et al., 1979; Ekdale et al., 1984 など). また堆 積残留磁化が獲得されるためには, 生物攪乱による堆積物粒 子の再配列が止まる必要があることから, 小竹 (2000) は海 底堆積物中の磁化獲得深度が少なくとも混合層より下位に位 置するはずであることを指摘した．以上のことを考慮する と, 海底堆積物中の $\mathrm{pDRM}$ 獲得の主要な原因は, 埋積に伴 う圧密による自由空間の減少ではなく, 生物擾乱の影響が無 くなり粒子の再配列が起こらなくなることであるといえる. また最低限生物靦乱が及ぶ厚さ分の磁化獲得深度が常に存在 すると考えられる.

LR04 で Matuyama/Gauss 境界を求めるために用いた堆 積物コアの堆積速度はおよそ 1-3 cm/ kyr 程度である (Hodell et al., 2003; Chen et al., 2004 等).これらのコア における磁化獲得深度を仮に $20 \mathrm{~cm}$ とした場合, Matuyama/Gauss 境界は最大で $20 \mathrm{kyr}$ 程度古く記録されるこ とになる. 本研究の古地磁気記録については, 磁化獲得深度 を上総層群で報告された最大值と同様に $40 \mathrm{~cm}$ 程度と仮定 しても, 南朝夷層の平均堆積速度 (約 $70 \mathrm{~cm} / \mathrm{kyr}$ ) から考え て, 磁化獲得時期の時間軸上の逆行は少なくとも千年以下と なる. また地中海セクションでは, 腐泥堆積時は底層水が酸 欠となり生物擾乱が無かったため, 全体セクションの平均的 な磁化獲得深度も通常と比べ浅いと考えられる. つまり地中 海セクションでは通常の深海底コアと比べ, 古地磁気記録一 MIS 間のより直接的な対比が可能であるといえる. これら のことを考慮すると, 本論文と LR04 における Matuyama/ Gauss 境界の位置の差異は, 堆積速度の遅い深海底コアに おいて磁化獲得のためにより多くの時間が必要とされること に起因し, Matuyama/Gauss 境界は, MIS 104 ではなく MIS 103 に対応すると結論できる.

本論文で構築した年代モデルにより算出される堆積速度 (Fig. 6) は, 0.37〜0.94 m/kyr の間にある. この変動範囲 は 2.5 倍程度に収まっており, 布良層〜南朝夷層の間に不整 合や無整合等, 堆積間隙の存在を示す極端な堆積速度低下は 見られなかった. 小竹(1988)では, 布良層一南朝夷層の間を 不整合であるとし，川上・宍倉 (2005)では, 同層準付近に 断層を推定したが, 今回の結果は, 少なくとも本論文におけ る調査ルート上では不整合や大きく層序を乱すような断層が 存在する可能性が低いことを示した.

\section{おわりに}

本研究では, 古地磁気層序および底生有孔虫化石による酸 素同位体層序を基に, 千倉層群における鮮新統一更新統境界 付近の詳細な年代モデルを構築した. これにより, 当該年代 周辺における高解像度古海洋学的研究の実施への足がかりが できたといえよう. さらにこれまで見解の相違があった Matuyama/Gauss 逆転境界とMIS との関係については, MIS 103 に対比される可能性が高いことがわかつた. この 
結果は, 地磁気年代スケールの発展に寄与するものである. 深海底コアにおける磁気逆転境界と MIS との対応関係につ いては，Matuyama/Gauss 境界より以前について特に記録 が少なく, 今後千倉層群のように良質の記録が得られる地層 で検証していく必要がある.

\section{謝 辞}

本研究は, 科学研究費補助金 (基盤研究 $(\mathrm{C})$; 課題番号 20540453）「房総半島に分布する海成堆積層を用いた，鮮 新統〜更新統における高精度基準層序の確立」の助成を受け て行った. 同位体測定は，高知コアセンター共同利用 （H18B-H21B）「房総半島に分布する鮮新〜更新統の酸素 同位体層序」によって行つた. また同位体測定について，高 知コアセンターの池原実准教授および技術補佐員の小林美智 代氏には大変お世話になった．高知コアセンターの安田尚人 教授および東京大学大気海洋研究所の朝日博史博士には底生 有孔虫化石の同定に関してご教授いただいた．また岡田研究 室の卒業生である中村友則氏および松田瞳氏には測定デー夕 の一部を提供していただいた．担当編集委員である名古屋大 学の井龍康文教授および查読者である産業技術総合研究所の 高橋雅樹博士，千葉大学の小竹信宏教授には原稿の改善に関 して大変お世話になった. 以上の方々に感謝申し上げます.

\section{文献}

Berger, W. H., Ekdale, A. A. and Bryant, P. P., 1979, Selective preservation of burrows in deep-sea carbonates. Marine Geol., 32, 205-230.

Chen, X., Zhao, Q., Wang, J., Jian, Z., Xia, P., Huang, B., Fang, D., Xu, J., Zhou, Z. and Wang, P., 2004, Data report: Stable isotopes from Sites 1147 and 1148. In Prell, W. L., Wang, P., Blum, P., Rea, D. K. and Clemens, S. C. (Eds.), Proc. ODP, Sci. Results, 184 [Online].

deMenocal, P. B., Ruddiman, W. F. and Kent, D. V., 1990, Depth of post-depositional remanence acquisition in deepsea sediments: a case study of the Brunhes-Matuyama reversal and oxygen isotopic Stage 19.1. Earth Planet. Sci. Lett., 99, 1-13.

Ekdale, A. A., Muller, L. N. and Novak, M. T., 1984, Quantitative ichnology of modern pelagic deposits in the abyssal Atlantic. Palaeogeogr., Palaeoclimatol., Palaeoecol., 45, 189223

Gradstein, F. M., Ogg, J. G. and Smith, A. G. (Eds.), 2004, A Geological Time Scale 2004. Cambridge Univ. Press, 610p.

Gradstein, F. M., Ogg, J. G. and van Kranendonk, M., 2008, On the Geological Time Scale 2008. Newsl. Stratigr., 43, 5-13.

Hodell, D. A., Charles, C. D., Curtis, J. H., Mortyn, P. G., Ninnemann, U. S. and Venz, K. A., 2003, Data report: Oxygen isotope stratigraphy of ODP Leg 177 Sites 1088, 1089, 1090, 1093, and 1094. In Gersonde, R., Hodell, D. A. and Blum, P. (Eds.), Proc. ODP, Sci. Results, 177 [Online].

Hyodo, M., 1984, Possibililty of reconstruction of the past geomagnetic field from homogeneous sediment. Jour. Geomagn. Geoelectr., 36, 45-62.

亀尾浩司・斎藤敬二・小竹信宏・岡田 誠 (Kameo, K., Saito, K., Kotake, N. and Okada, M.), 2003, 房総半島南端, 千倉層群下 部の石灰質ナンノ化石に基づく本邦中部太平洋側の後期鮮新世 表層海洋環境. 地質雑 (Jour. Geol. Soc. Japan), 109, 478488

川上俊介 · 宾倉正展 (Kawakami, S. and Shishikura, M.), 2006, 館 山地域の地質. 地域地質研究報告 (5 万分の 1 地質図幅) (Geol- ogy of the Tateyama Districts. Quadrangle Ser. Scale 1: 50000), 産総研地質調査総合センター(Geol. Surv. Japan, AIST), 82p

Kent, D. V., 1973, Post-depositional remanent magnetization in deep-sea sediment. Nature, 246, 32-34.

小竹信宏 (Kotake, N.), 1988, 房総半島南端地域の海成上部新生界. 地質雑 (Jour. Geol. Soc. Japan), 94, 187-206.

小竹信宏・ 小山真人 - 龟尾浩司 (Kotake, N., Koyama, M. and Kameo, K.) , 1995, 房総半島南端地域に分布する千倉・豊房層群 (鮮新一更新統) の古地磁気および微化石層序. 地質雑(Jour. Geol. Soc. Japan), 101, 515-531.

小竹信宏 (Kotake, N.), 2000, 生物攪乱 : メカニズム, プロセス, 物 理・化学的影響. 奈良正和編, ダイナミック古生態学 古環境と化 石底生群集との相互作用 古生物学トピックス No. 1, 日本古生物 学会 (Paleont. Soc. Japan), 3-36.

Laskar, J., Joutel, F. and Boudin, F., 1993, Orbital, precessional and insolation quantities for the Earth from $-20 \mathrm{Myr}$ to + $10 \mathrm{Myr}$. Astronomy and Astrophysics, 270, 522-533.

Lisiecki, L. E. and Raymo, M. E., 2005, A Pliocene-Pleistocene stack of 57 globally distributed benthic $\delta^{18} \mathrm{O}$ records. Paleoceanography, 20, PA1003, doi: 10. 1029/2004PA001071.

Liu, Q., Roberts, A. P., Rohling, E. J., Zhu, R. and Sun, Y., 2008, Post-depositional remanent magnetization lock-in and the location of the Matuyama-Brunhes geomagnetic reversal boundary in marine and Chinese loess sequences. Earth Planet. Sci. Lett., 275, 102-110.

Lourens, L. J., Antonarakou, A., Hilgen, F. J., Van Hoof, A. A. M., Vergnaud-Grazzini, C. and Zachariasse, W. J., 1996, Evaluation of the Plio-Pleistocene astronomical timescale. Paleoceanography, 11, 391-413.

Lourens, L. J., Hilgen, J., Shackleton, F. J., Laskar, N. J. and Wilson, D., 2005a, The Neogene period. In Gradstein, F. M., Ogg, J. G. and Smith, A. G. (Eds), A Geological Time Scale 2004, Cambridge Univ. Press, 409-440.

Lourens, L. J., Hilgen, J., Shackleton, F. J., Laskar, N. J. and Wilson, D., 2005b, Orbital tuning calibration and conversions for the Neogene Period. In Gradstein, F. M., Ogg, J. G. and Smith, A. G. (Eds), A Geological Time Scale 2004, Cambridge Univ. Press, 469-484.

McFadden, P. L. and McElhinny, M. W., 1990, Classification of the reversal test in paleomagnetism. Geophys. Jour. Intern., 103, 725-729.

成瀬 洋・杉村 新 - 小池 清(Naruse, Y., Sugimura, A. and Koike, K.), 1951, 房総南端: 新第三紀層. 地質雑 (Jour. Geol. Soc. Japan), 57, 511-525.

岡田 誠・永田 潤・永塚 歩・ 中山陽平 (Okada, M., Nagata, J., Nagatsuka, A. and Nakayama, Y.), 2006, 南房総に分布する鮮 新統千倉層群布良層の酸素同位体層序. 日本地質学会第 113 年 学術大会講演要旨(Abstr. 113th Ann. Meet. Geol. Soc. Japan), 188

岡田 誠 - 所 佳実 - 松田 瞳 - 内田剛行 (Okada, M., Tokoro, Y., Matsuda, H. and Uchida, Y.), 2010, 南房総に分布する鮮新一 更新統千倉層群の酸素同位体層序(予報)。 日本地質学会第 117 年学術大会講演要旨 (Abstr. 117th Ann. Meet. Geol. Soc. Japan), 78 .

Okada, M. and Niitsuma, N., 1989, Detailed paleomagnetic records during the Brunhes-Matuyama geomagnetic reversal, and direct determination of depth lag for magnetization in marine sediments. Phys. Earth Planet. Inter. 56, 133-150.

Shackleton, N. J. and Hall, M. A., 1984, Oxygen and carbon isotope stratigraphy of DSDP Hole 552A: Plio-Pleistocene glacial history. Initial Rep. Deep Sea Drill. Project, 81, 599 -609 .

Suganuma, Y., Yokoyama, Y., Yamazaki, T., Kawamura, K., Horng, C. -H. and Matsuzaki, H., 2010, ${ }^{10} \mathrm{Be}$ evidence for delayed acquisition of remanent magnetization in marine sediments: Implication for a new age for the MatuyamaBrunhes boundary. Earth Planet. Sci. Lett., 296, 443-450. 
Tauxe, L., Steindorf, J. L. and Hariis, A., 2006, Depositional remanent magnetization: Toward and improved theoretical and experimental foundation. Earth Planet. Sci. Lett., 244, 515-529.

Tiedemann, R., Sarnthein, M. and Shackleton, N. J., 1994, Astronomic timescale for the Pliocene Atlantic $\delta^{18} \mathrm{O}$ and dust flux records of Ocean Drilling Program Site 659. Pale- oceanography, 9, 619-638.

Tsunakawa, H., Okada, M. and Niitsuma, N., 1999, Further application of the deconvolution method of post-depositional DRM to the precise record of the Matuyama-Brunhes reversal in the sediments from the Boso Peninsula, Japan. Earth Planets Space, 51, 169-173.

(要 旨)

岡田 誠·所 佳実 ·内田剛行 · 荒井裕司・斉藤敬二, 2012, 房総半島南端千倉層群にお ける鮮新統一更新統境界層準の古地磁気一酸素同位体複合層序. 地質雑, 118, 97-108. (Okada, M., Tokoro, Y., Uchida, Y., Arai, Y. and Saito, K., 2012, An integrated stratigraphy around the Plio-Pleistocene boundary interval in the Chikura Group, southernmost part of the Boso Peninsula, central Japan, based on data from paleomagnetic and oxygen isotopic analyses. Jour. Geol. Soc. Japan, 118, 97-108.)

古地磁気および底生有孔虫化石の酸素同位体デー夕を基に, 房総半島南端に分布する鮮 新一更新統境界を含む千倉層群の中部層準における詳細な編年を行つた. その結果, 検討層 準が Kaena 逆磁極亜帯を含む Gauss 正磁極帯上部から松山逆磁極帯下部に, LR04 酸素 同位体標準カーブにおける海洋同位体ステージ (MIS) G16〜93 の間に対応することがそれ ぞれ判明した. また LR04 タイムスケールで MIS 104 とされていた Matuyama/Gauss 境 界は，MIS 103 に相当することがわかつた.この結果は，ATNTS2004 で採用されている 地中海の腐泥層序で見られる同境界の層位学的位置と一致する. 